\title{
Identification and Synthesis of Putative Pheromone Components of the Threatened Salt Marsh Bagworm Moth, Whittleia retiella (Lepidoptera: Psychidae)
}

\author{
Rizan Rahmani ${ }^{1}$ - David Carrasco ${ }^{2,3}$ - Glenn P. Svensson ${ }^{4} \cdot$ Hartmut Roweck $^{5}$ - Nils Ryrholm ${ }^{6}$ - Mattias C. Larsson ${ }^{2}$. \\ Erik Hedenström ${ }^{1}$ (D)
}

Received: 16 January 2019 /Revised: 4 June 2019 / Accepted: 3 January 2020 /Published online: 13 February 2020

(C) The Author(s) 2020

\begin{abstract}
Whittleia retiella (Newman, 1847) is a threatened salt marsh species of the bagworm moth family Psychidae. For its preservation it is necessary to develop efficient tools to survey its distribution and habitat requirements in order to use appropriate conservation methods. Such tools may be pheromone-based monitoring systems, which have documented efficacy in establishing the occurrence of cryptic insect species in nature. By using gas chromatography combined with electroantennographic detection (GCEAD), we found two compounds in female W. retiella headspace samples and whole-body extracts that elicited electrophysiological activity in male antennae. Gas chromatograpy coupled with mass spectrometry (GC-MS) operating in electron impact (EI) mode and comparison of the analytical data with those of synthetic reference compounds showed the chemical structures of these putative pheromone components to be (1S)-1-methylpropyl (5Z)-dec-5-enoate and 1-methylethyl (5Z)-dec-5-enoate. Field assays using baits loaded with synthetic compounds revealed that conspecific males were attracted to (1S)-1-methylpropyl (5Z)-dec-5enoate alone or in combination with 1-methylethyl (5Z)-dec-5-enoate, whereas 1-methylethyl (5Z)-dec-5-enoate neither attracted nor repelled males in the field assays when tested alone. This study shows the potential of using (1S)-1-methylpropyl (5Z)-dec-5enoate for monitoring $W$. retiella to gather more detailed information about the geographic distribution and habitat needs of this rare moth.
\end{abstract}

Keywords Endangered species $\cdot$ Species monitoring $\cdot$ Field observation $\cdot 1$-Methylethyl (5Z)-dec-5-enoate $\cdot(1 S)$-1-Methylpropyl (5Z)-dec-5-enoate $\cdot$ Stereoisomers $\cdot$ Enantiomers

Electronic supplementary material The online version of this article (https://doi.org/10.1007/s10886-020-01145-x) contains supplementary material, which is available to authorized users.

Mattias C. Larsson

mattias.larsson@slu.se

Erik Hedenström

erik.hedenstrom@miun.se

1 Eco-Chemistry, Department of Chemical Engineering, Mid Sweden University, SE-851 70 Sundsvall, Sweden

2 Department of Plant Protection Biology, Swedish University of Agricultural Sciences, Box 102, SE-230 53 Alnarp, Sweden

3 Present address: MIVEGEC, University of Montpellier, IRD, CNRS, Montpellier, France

4 Department of Biology, Lund University, Lund SE-223 62, Sweden

5 Faculty of Agricultural and Nutritional Sciences, Christian Albrecht University, Olshausenstraße 75, R. 220 Kiel, Germany

6 Department of Electronics, Mathematics and Natural Sciences, Faculty of Engineering and Sustainable Development, University of Gävle, SE-801 76 Gävle, Sweden

\section{Introduction}

Insect sex pheromones have traditionally been studied for the purpose of pest control (Witzgall et al. 2010). More recently, significant efforts have been made to develop pheromonebased monitoring systems also for rare and threatened species as a novel tool in conservation biology (Larsson 2016). Sex pheromones can be used to detect target species even at very low population densities and thus have high potential for monitoring population dynamics, habitat needs, and changes in the geographic distribution of red-listed insect species, which would otherwise be difficult to assess. Access to efficient monitoring systems may, in turn, allow to serve as indicators of the conservation status of habitats for these species that are in danger of being destroyed or degraded.

The majority of sex pheromone identifications in rare and threatened insects have so far been limited to a few groups, predominantly beetles. These include scarabaeids such as the hermit beetle species Osmoderma eremita and Osmoderma barnabita (Larsson et al. 2003; Svensson et al. 2009), which 
constituted the first model species for pheromone identifications specifically for conservation purposes, and the noble chafer Gnorimus nobilis (Harvey et al. 2018), several click beetle species such as Elater ferrgineus (Tolasch et al. 2007), Betarmon bisbimaculatus (Koenig et al. 2015), and Idolus picipennis (Koenig et al. 2016) and longhorn beetles such as Prionus coriarius (Barbour et al. 2011), Rosalia alpina (Kosi et al. 2017), Phymatodes pusillus (Molander and Larsson 2018), and Plagionotus detritus (Molander et al. 2019). To date, only a limited number of rare and endangered moth species have been investigated e.g. the Spanish moon moth Graellsia isabellae (Millar et al. 2010), and the clearwing moth Synanthedon vespiformis (Burman et al. 2016).

The bagworm family Psychidae includes approximately 1000 species of small to medium sized moths. A distinct characteristic of this archaic family is that individuals complete larval development within a self-enclosing bag (Heppner 2008), and females of many species are wingless or have reduced wings. Unlike most moth species, which emit the sex pheromone from a gland at the tip of the abdomen, female bagworms release their pheromone from specific gland cells located on the thorax and/or the anterior part of the abdomen (Leonhardt et al. 1983; Subchev et al. 2000). The Psychidae include several important pests, but also rare and endangered species. One such species, whose conservation may benefit from pheromone monitoring and which would potentially constitute a good indicator species for landscape preservation is Whittleia retiella Newman, 1847 (Lepidoptera: Psychidae). Adult males of W. retiella have a wingspan of 7.5-8.5 mm, whereas females are wingless with rudimentary pairs of legs (Rickert et al. 2009). The species is a salt marsh specialist, whose larvae use grasses such as Puccinellia maritima (Poaceae) to feed on and eventually pupate. This rare halobiotic moth flies at the end of April or the beginning of May (Bengtsson and Palmqvist 2008; Ryrholm 2005). It is listed in the Red List of endangered animals of Germany as very rare (Binot et al. 1998) and in Sweden as critically endangered (Ahrné et al. 2015).

W. retiella could be considered an important indicator species for salt marshes that extend along the North Sea coast from Denmark to the Netherlands. Salt marshes are characterised by shifting tides and varying salt concentrations, providing a habitat for a number of characteristic species as well as constituting breeding grounds and a stopover habitat for migrating waders and shorebirds. The salt marshes are products of long periods of management by grazing, which is prerequisite for their long-term persistence. An important aspect of their preservation is to manage grazing intensity to maintain high biodiversity. Because $W$. retiella appears to be largely dependent on relatively well-managed marshland for its persistence, it could serve as an indicator for favourable management (Rickert et al. 2009; Rickert 2010). Due to its minute size and clandestine lifestyle, the species is extremely hard to find, and a pheromone would thus be a valuable tool for monitoring of $W$. retiella and the quality of its habitats.

In the present study, we identify two compounds, $(1 S)-1$ methylpropyl (5Z)-decenoate and 1-methylethyl (5Z)decenoate, released by female $W$. retiella, which are sex pheromone component candidates based on the electrophysiological and behavioural activity they trigger in conspecific males. Syntheses and analytical data of these compounds and compounds used for reference are also presented in this work.

\section{Methods and Materials}

Collection of Moths Specimens were collected in 2010 and 2012 from the salt marshes and grasslands by the North Sea coast at Westerhever, Nordfriesland, Germany. Larval and pupal cases made of small fragments of dry grass spun together were collected, and larvae were sorted by weight and separated by sex. Generally, females were heavier than males. Larvae were kept in Petri dishes together with living plants of P. maritima to feed on until pupation. Emerging males were collected and placed in plastic tubes with cotton stoppers in the fridge until use for electrophysiological analyses. Female pupae were either left inside their pupal cases and used for repeated odour collections or carefully removed from their cases using thin forceps for direct extraction (see below).

\section{Collection of Putative Pheromone Components Between 6} and 42 adult females (less than one week old) were pooled into $20 \mathrm{~mL}$ glass scintillation vials with two holes made in the lids. One hole was fitted with an activated charcoal filter through which air entered the vial, while the other was fitted with an odour collection filter made from Teflon tubing (60 mm with I.D. $3.0 \mathrm{~mm}$ O.D. $4.0 \mathrm{~mm}$ ) and containing $25 \mathrm{mg}$ Porapak Q (PQ) mesh size 80/100 (Sigma-Aldrich, St. Louis, MO, USA) as adsorbent material. Air was pumped through the vial and the collection filter at $0.2 \mathrm{~L} / \mathrm{min}^{-1}$ for several hours (range: 17-24 hr) during 4 consecutive days, using a KNF NMP830KNDC air pump (KNF Neuberger, Balterswil, Switzerland). Long and sequential collection times were justified since the calling time of the females during the day was unknown. The PQ filters were changed every day. After collection, the filters were extracted with $2 \times 150 \mu \mathrm{l}$ redistilled $n$-hexane, which was collected in $1.5 \mathrm{~mL}$ glass vials and stored at $-20{ }^{\circ} \mathrm{C}$ until further use. In addition, 15 females were removed from their old pupal cases and extracted for $30 \mathrm{~min}$ in $1 \mathrm{~mL} n$-hexane, which was later concentrated to $300 \mu \mathrm{l}$ under $\mathrm{N}_{2}$ and stored in $1.5 \mathrm{~mL}$ glass vials at $-20^{\circ} \mathrm{C}$ until further use.

Electrophysiology In order to screen for putative pheromone components, headspace samples and whole-body extracts of 
female moths (less than one week old) were analysed using combined gas chromatography and electroantennographic detection (GC-EAD) (Larsson and Svensson 2005). The head of a male moth with both antennae was mounted to a PRG-2 EAG Probe $(10 \times$ gain) (Syntech, Kirchzarten, Germany) using conductive gel (Blågel, Cefar, Malmö, Sweden). The GC effluent passed through a heated transfer line set at $255^{\circ} \mathrm{C}$ and was mixed with charcoal-filtered and humidified air before reaching the antennal preparation, which was positioned $1 \mathrm{~cm}$ from the glass tube outlet. Extracts or headspace samples $(2 \mu \mathrm{l})$ were injected into an Agilent $7890 \mathrm{~A}$ gas chromatograph (Agilent Technologies, Palo Alto, CA, USA), equipped with a polar HP-INNOWax column $(30 \mathrm{~m} \times$ $0.25 \mathrm{~mm}$ I.D. $\times 0.25 \mu \mathrm{m}$ film thickness; J\&W Scientific, Agilent Technologies, Santa Clara, CA, USA) operated in splitless mode. Hydrogen was used as carrier gas at a flow rate of $1 \mathrm{~mL} \cdot \mathrm{min}^{-1}$, and the injector temperature was $250{ }^{\circ} \mathrm{C}$. The GC effluent was split at a 1:1 ratio between the flame ionisation detector (FID) and the antennal preparation. The oven temperature was maintained at $50^{\circ} \mathrm{C}$ for $1 \mathrm{~min}$ after injection and then increased to $210^{\circ} \mathrm{C}$ at a rate of $10^{\circ} \mathrm{C} \cdot \mathrm{min}^{-1}$ and a final hold of $10 \mathrm{~min}$. Additional analyses were performed on an HP $6890 \mathrm{~N}$ gas chromatograph equipped with a non-polar HP-5 column $(30 \mathrm{~m} \times 0.32 \mathrm{~mm}$ I.D. $\times 0.25 \mu \mathrm{m}$ film thickness, J\&W Scientific). For these analyses, an antenna was mounted between two glass capillaries filled with Beadle-Ephrussi ringer solution and connected to a preamplifier $(10 \times$ gain) $($ Syntech). The GC effluent passed through a Gerstel ODP-3 transfer line, which was temperature adjusted in tandem with the GC oven temperature. It was mixed with charcoal-filtered and humidified air before reaching the antenna, placed $0.5 \mathrm{~cm}$ apart from the glass tube outlet. Hydrogen was used as carrier gas at an average linear flow of $45 \mathrm{~cm} \cdot \mathrm{s}^{-1}$ and an injector temperature of $225^{\circ} \mathrm{C}$. The GC effluent was split 1:1 in a Gerstel 3D/2 low dead volume fourway-cross (Gerstel, Mülheim, Germany) with 4 psi of nitrogen added through the fourth connection. The oven temperature was maintained at $50^{\circ} \mathrm{C}$ for $3 \mathrm{~min}$ after injection and increased by $10{ }^{\circ} \mathrm{C} \cdot \mathrm{min}^{-1}$ to $230{ }^{\circ} \mathrm{C}$, with a final hold of $10 \mathrm{~min}$. All recordings were performed using the GC-EAD Pro ver. 4.1 software (Syntech).

Chemical Analysis Tentative identification of the female-produced, antennally active compounds was performed by GCMS with column types matching the columns used for GCEAD recordings. An HP-5 ms capillary column $(60 \mathrm{~m} \times 0.25$ I.D. $\times 0.25 \mu \mathrm{m}$ film thickness, Agilent Technologies) was mounted in a GC $6890 \mathrm{~N}$ model GC interfaced to a 5975 mass selective detector (Agilent Technologies, Palo Alto, CA, USA). The carrier gas was helium with a constant flow rate of $1.8 \mathrm{~mL} \cdot \mathrm{min}^{-1}$ (inlet pressure $172 \mathrm{kPa}$ ) at an injector temperature of $225{ }^{\circ} \mathrm{C}$. Analyses started at $30^{\circ} \mathrm{C}$ with a $3 \mathrm{~min}$ hold and programmed to $250^{\circ} \mathrm{C}$ at a rate of $8{ }^{\circ} \mathrm{C} \cdot \mathrm{min}^{-1}$. The transfer line temperature started at $150{ }^{\circ} \mathrm{C}$ and was then set to remain $10^{\circ} \mathrm{C}$ above the oven temperature. Sample injections of $2 \mu \mathrm{L}$ of extracts were made manually in splitless mode (split vent opened after $0.5 \mathrm{~min}$ ). Headspace samples were also analysed using an HP 5890II gas chromatograph linked to an HP 5972 mass spectrometer equipped with an HPINNOWax column $(30 \mathrm{~m} \times 0.25 \mathrm{~mm}$ I.D. and $0.25 \mu \mathrm{m}$ film thickness; J\&W Scientific). Helium was used as the carrier gas at a velocity of $40 \mathrm{~cm} \cdot \mathrm{s}^{-1}$ and an injector temperature of $220^{\circ} \mathrm{C}$. After injection in splitless mode, the oven temperature was maintained at $50{ }^{\circ} \mathrm{C}$ for $2 \mathrm{~min}$ and then increased by $10^{\circ} \mathrm{C} \cdot \mathrm{min}^{-1}$ to $250{ }^{\circ} \mathrm{C}$, with a final hold for $10 \mathrm{~min}$.

More detailed investigations of insect extracts were performed on a Hewlett-Packard 6890 N GC using a HP 5973 mass spectrometer operating in electron impact mode $($ EI, $70 \mathrm{eV})$. Helium was used as the carrier gas (flow rate $=1.0 \mathrm{~mL} \cdot \mathrm{min}^{-1}$ ), and the split/splitless injector was operated in splitless mode for $2.5 \mathrm{~min}$ at $250{ }^{\circ} \mathrm{C}$. The transfer line was maintained at $250{ }^{\circ} \mathrm{C}$, and the MS source was set to $230{ }^{\circ} \mathrm{C}$. Two different capillary columns were used: i) a $30 \mathrm{~m} \times 0.25 \mathrm{~mm}$ I.D. $\times 0.25 \mu \mathrm{m}$ film thickness fused silica capillary column VF-23 ms (Agilent Technologies); temperature program from $50{ }^{\circ} \mathrm{C}$ to $230{ }^{\circ} \mathrm{C}$ at a rate of $10{ }^{\circ} \mathrm{C} \cdot \mathrm{min}^{-1}$, then held at $230{ }^{\circ} \mathrm{C}$ for $10 \mathrm{~min}$ and, ii) a $30 \mathrm{~m} \times 0.25$ I.D. $\times$ $0.25 \mu \mathrm{m}$ film thickness fused silica capillary column CP-WAX 58 (Agilent Technologies); initial temperature $50{ }^{\circ} \mathrm{C}$, held for $2 \mathrm{~min}$, then increased to $100{ }^{\circ} \mathrm{C}$ at a rate of $10{ }^{\circ} \mathrm{C} \cdot \mathrm{min}^{-1}$, and then held at $100{ }^{\circ} \mathrm{C}$ for $35 \mathrm{~min}$.

For the separation of enantiomers, a Hewlett-Packard 6890 N GC linked to a HP 5973 mass spectrometer was used with helium as the carrier gas (flow rate $=1.0 \mathrm{~mL} \cdot \mathrm{min}^{-1}$ ). The split/splitless injector was operated in splitless mode and set at $250{ }^{\circ} \mathrm{C}$. The transfer line was maintained at $250{ }^{\circ} \mathrm{C}$, and the MS source was set to $230^{\circ} \mathrm{C}$. The GC was equipped with a fused silica capillary column $(30 \mathrm{~m} \times 0.25 \mathrm{~mm}$ ID $\times 0.25 \mu \mathrm{m}$ film thickness) coated with Cyclosil-B (Agilent Technologies). Separations were performed using a temperature program starting at $50^{\circ} \mathrm{C}$ ( 2 min hold $)$, then increased to $250{ }^{\circ} \mathrm{C}$ at a rate of $5^{\circ} \mathrm{C} \cdot \mathrm{min}^{-1}$.

Data Analysis The raw MS data were analysed using the Workstation v7.0.0 program (Agilent). Compounds were analysed by comparing the mass spectra of natural products with data reported in the NIST MS 2.0 mass spectral library, using reverse and forward match values. The postulated structures were also confirmed by comparing retention times and mass spectra of the natural compounds with those of synthetic samples.

Commercial Chemicals (4E)-Dec-4-enoic acid was obtained from Penta International Corporation company, (4Z)-dec-4- 
en-1-ol and (5E)-dec-5-en-1-ol were purchased from TCI Europe, and (5Z)-dec-5-en-1-ol was obtained from Bedoukian Research Inc., Danbury, CT, USA. Candida rugosa lipase (CRL), (5-carboxypentyl)triphenylphosphonium bromide, and racemic butan-2-ol and propan-2-ol were purchased from Sigma-Aldrich, whereas (2R)-butan-2-ol and (2S)-butan-2-ol were obtained from Alfa-Aesar (Haverhill, Massachusetts, USA). All chemicals and solvents were of the highest available purity i.e. $>95 \%$.

Synthesis of Acids (4Z)-Dec-4-enoic acid, (5E)-dec-5-enoic acid, and (5Z)-dec-5-enoic acid were prepared via oxidation of (4Z)-dec-4-en-1-ol, (5E)-dec-5-en-1-ol, and (5Z)-dec-5-en1-ol, respectively, according to Bowden (Bowden et al. 1946). Dec-6-enoic acid was synthesised via Wittig reaction from (5carboxypentyl)triphenylphosphonium bromide, sodium hexamethyldisilylamide (NaHDMS), and butanal in THF according to Wube (Wube et al. 2011). For details of the syntheses and analytical data see Supplementary Material.

General Synthesis of Reference Esters In typical FischerSpeier esterification reactions a carboxylic acid, an alcohol (in excess amount), and a catalytic amount of sulfuric acid $(2 \mathrm{M})$ were mixed in a round-bottom flask. The contents were heated on a boiling water-bath and stirred for different lengths of time. For details of the syntheses and analytical data see Supplementary Material.

Lipase Catalyzed Esterification A facile enzymatic esterification process using crude lipase CRL as a biocatalyst in an organic solvent for the direct synthesis of (2S)-1-methylpropyl (5Z)-dec-5-enoate and (2R)-1-methylpropyl (5Z)-dec-5enoate. (5Z)-Dec-5-enoic acid and (2R)-butan-2-ol as well as (2S)-butan-2-ol were used according to Sabbani et al. (2007) and Chang and Hsu (2003). For description of analytical data and the synthesis see Supplementary Material.

Preparation of Baits Lures with synthetic pheromone candidate compounds were prepared by dissolving known amounts of compounds by weight in redistilled $n$-hexane. Samples were prepared to obtain single-compound solutions or blends with desired amounts of test compounds. Solutions were pipetted as $100 \mu \mathrm{l}$ aliquots into the cups of hollow red rubber septa (11 $\times 5$ mm, \#224100-020; Wheaton Science Products, Millville, NJ, USA) and the hexane allowed to evaporate in a fume hood after being partially adsorbed into the septum. Two sets of baits were prepared (Table 1). The first set was originally prepared in 2015 and included a broad range of combinations of the racemate and enantiomers of 1-methylpropyl (5Z)-dec-5-enoate. The second set, prepared in 2016, included a more limited number of blends comprising only the
(S)-enantiomer. Each bait type was individually marked with a felt-tip pen. Baits were stored individually in the freezer when not in use and were brought out in the field for short periods (a few hours per day) during approximately one week during each season over several years.

Field Bioassays Attempts to observe the attraction of male W. retiella to synthetic baits were performed in 2015-2018 at several localities in Denmark in biotopes corresponding to preferred habitats of the species (NW Jutland: Hjelm Hede in Skive. NE Jutland: Mulbjerge at Dokkedal. Central Jutland: Kongenshus Hede and Gindeskov Krat, near Viborg. Dybdal Bæk, near Nørre Snede. E Jutland: Sejs Hede near Silkeborg). Observations of flying $W$. retiella at these localities are rare, and populations were expected to be very small. Therefore, no attempts were made to trap any insects with baits, but were based on observations of free-flying males approaching the different lures. Attempts to observe flights and attraction of W. retiella were limited to days of suitable weather with sun and limited wind during the expected short flight season in May-June. Behavioural observations of male attraction were performed by placing a series of rubber septa on the ground with individual septa at a distance of 50 $100 \mathrm{~cm}$ apart. Each septum was marked with an individual number or letter with a felt-tip pen, but the content of each septum was unknown to the observer. At each visit, the septa were displayed from one to several hours. Flying males approaching the septa were counted on each occasion, and their flight patterns with repeated approaches to individual septa were noted.

\section{Results}

Electrophysiology At first, we investigated the electrophysiological activity of male antennae of $W$. retiella when stimulated with female-produced compounds collected by headspace sampling or whole-body extraction. The GC-EAD analysis on a polar column (HP-INNOWax) showed that two compounds (X and Y), sampled with both methods, elicited electrophysiological activity in male antennae, indicating that they are candidates as sex pheromone components of $W$. retiella (Fig. 1). To minimise the possibility of overlapping peaks, the GC-EAD analysis was repeated on a less polar GC-column (HP5 ), which again resulted in antennal responses to two female specific compounds (data not shown).

Chemical Analysis Matching of the GC-EAD-active compounds with mass spectra were performed through comparisons of the peak profiles of GC-EAD-FID and GC- 
Table 1 Two different series of lures were prepared in 2015 (bold) and 2016 (italic), respectively

\begin{tabular}{|c|c|c|c|c|c|c|c|c|c|c|c|c|c|c|}
\hline Series & Compound & Blank & 1 & 2 & 3 & 4 & 5 & 6 & 7 & 8 & 9 & 10 & 11 & 12 \\
\hline Series 1 & Isoprop-C5DA & & & 10 & 30 & & 30 & 10 & 30 & 100 & & 10 & 30 & 50 \\
\hline \multirow[t]{4}{*}{ 2015- } & (rac)-2b-C5DA & & & & & 200 & 200 & 100 & 100 & & & & & \\
\hline & (S)-2b-C5DA & & & & & & & & & & 100 & 100 & 100 & 100 \\
\hline & (R)-2b-C5DA & & 100 & 100 & 100 & & & & & & & & & \\
\hline & Blank & Hexane & & & & & & & & & & & & \\
\hline Series 2 & Isoprop-C5DA & & & & & & & & & 100 & & 10 & 30 & 50 \\
\hline \multirow[t]{2}{*}{ 2016- } & (S)-2b-C5DA & & & & & & & & & & 100 & 100 & 100 & 100 \\
\hline & Blank & Hexane & & & & & & & & & & & & \\
\hline
\end{tabular}

Both sets of lures were used to varying extent from the years they were prepared. Numbers represent $\mu \mathrm{g}$ loading of different synthetic compounds onto the septa. Blank baits were loaded with solvent ( $n$-hexane) only. Isoprop-C5DA =1-methylethyl (5Z)-dec-5-enoate, 2b-C5DA $=1$-methylpropyl (5Z)dec-5-enoate. Different enantiomeric composition of 2b-C5DA $(S, R$ or racemic) is indicated

MS on the two different columns. Retention times of the earlier eluting minor component $\mathrm{X}$ and the later eluting major component $\mathrm{Y}$ differed significantly between the two columns, but the mass spectra of the two compounds matched on both DB-Wax and HP-5 columns. Subsequent GC-MS analysis of extracts was performed on a polar GC-column (Vf-23 ms). As seen in Fig. 2, the analysis showed highest masses at $\mathrm{m} / \mathrm{z} 212$ for compound $X$, eluting at $7.38 \mathrm{~min}$ and at $\mathrm{m} / \mathrm{z} 226$ for compound $\mathrm{Y}$, eluting at $8.27 \mathrm{~min}$, most probably representing the molecular ions $\left(\mathrm{M}^{+}\right)$of the two compounds. The observed losses of $42 \mathrm{amu}$ from $\mathrm{M}^{+}=212$ and 56 amu from $\mathrm{M}^{+}=226$ produced the same fragment of $\mathrm{m} / \mathrm{z} 170$ for both $\mathrm{X}$ and $\mathrm{Y}$ (Fig. 2).

The daughter ion at $\mathrm{m} / \mathrm{z} 170$ showed the same fragmentation pattern for both compounds. In fact, it suggested a decenoic acid fragment, produced upon McLafferty rearrangement of carboxylic acid esters, which is supported by the presence of signals at $\mathrm{m} / \mathrm{z} 153$ (acylium ion) and $\mathrm{m} / \mathrm{z}$ 152 (ketene fragment) (Francke et al. 2000). Consequently, the alcohol side of the esters X (MW 212) and Y (MW 226) would comprise 3 or 4 carbons, respectively. Checking the literature, revealed two plotted mass spectra of pheromones of Zygaenid moths: 1-methylpropyl (7Z)-tetradecenoate (Subchev et al. 1998) and 1-methylpropyl (7Z)-dodecenoate (Subchev et al. 2009). These spectra revealed fragmentation patterns similar to that of $\mathrm{X}$ and $\mathrm{Y}$, which further supported our hypotheses. By analogy, and considering the structure of 1methylethyl octanoate as another bagworm pheromone (Subchev et al. 2000), we concluded that the alcohol sides of $\mathrm{X}$ and $\mathrm{Y}$ could be represented by secondary alcohols rather than by primary ones. As a result, $\mathrm{X}$ was supposed to be a 1methylethyl decenoate, whereas $\mathrm{Y}$ should be a 1methylpropyl decenoate. However, the position of the double bonds remained to be determined. Very unfortunately, the small amounts of available natural material prohibited derivatisation, and we had to speculate: Considering that the biosynthetic pathways leading to the Zygaenid pheromones and to $\mathrm{X}$ and $\mathrm{Y}$ follow the same basic principles, it was

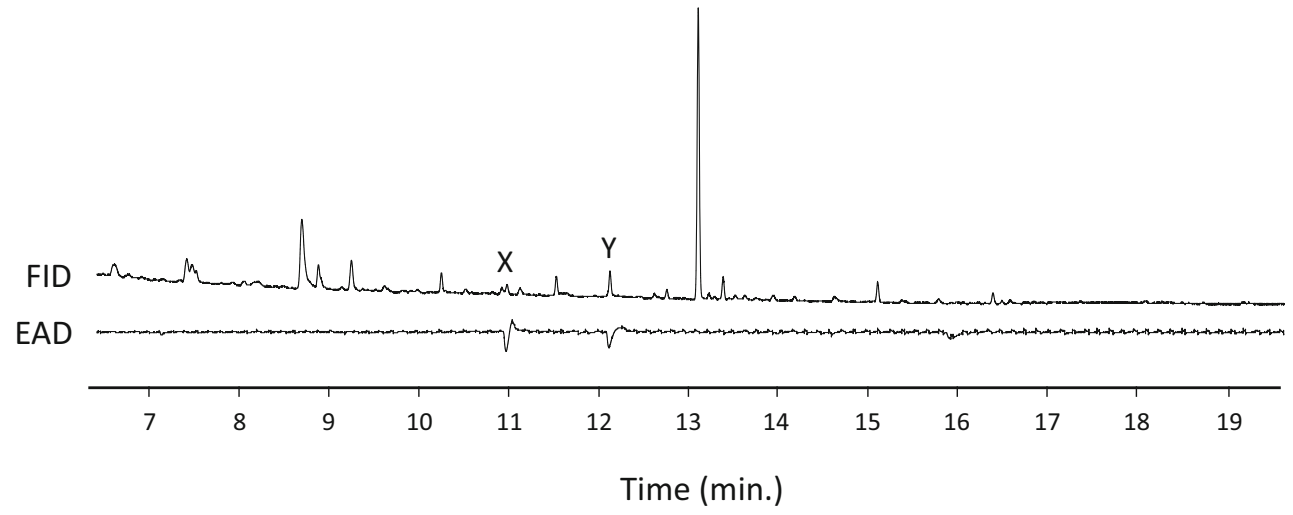

Fig. 1 Coupled gas chromatographic-electroantennographic (GC-EAD) analysis of a headspace sample from females of Whittleia retiella. The upper trace shows the response of the flame ionization detector (FID), and the lower trace shows the antennal response (EAD) of a conspecific male.
The analysis was perfomed using a polar HP-INNOWax column revealing the presence of two unknown physiologically active compounds, $\mathrm{X}$ and $\mathrm{Y}$ 

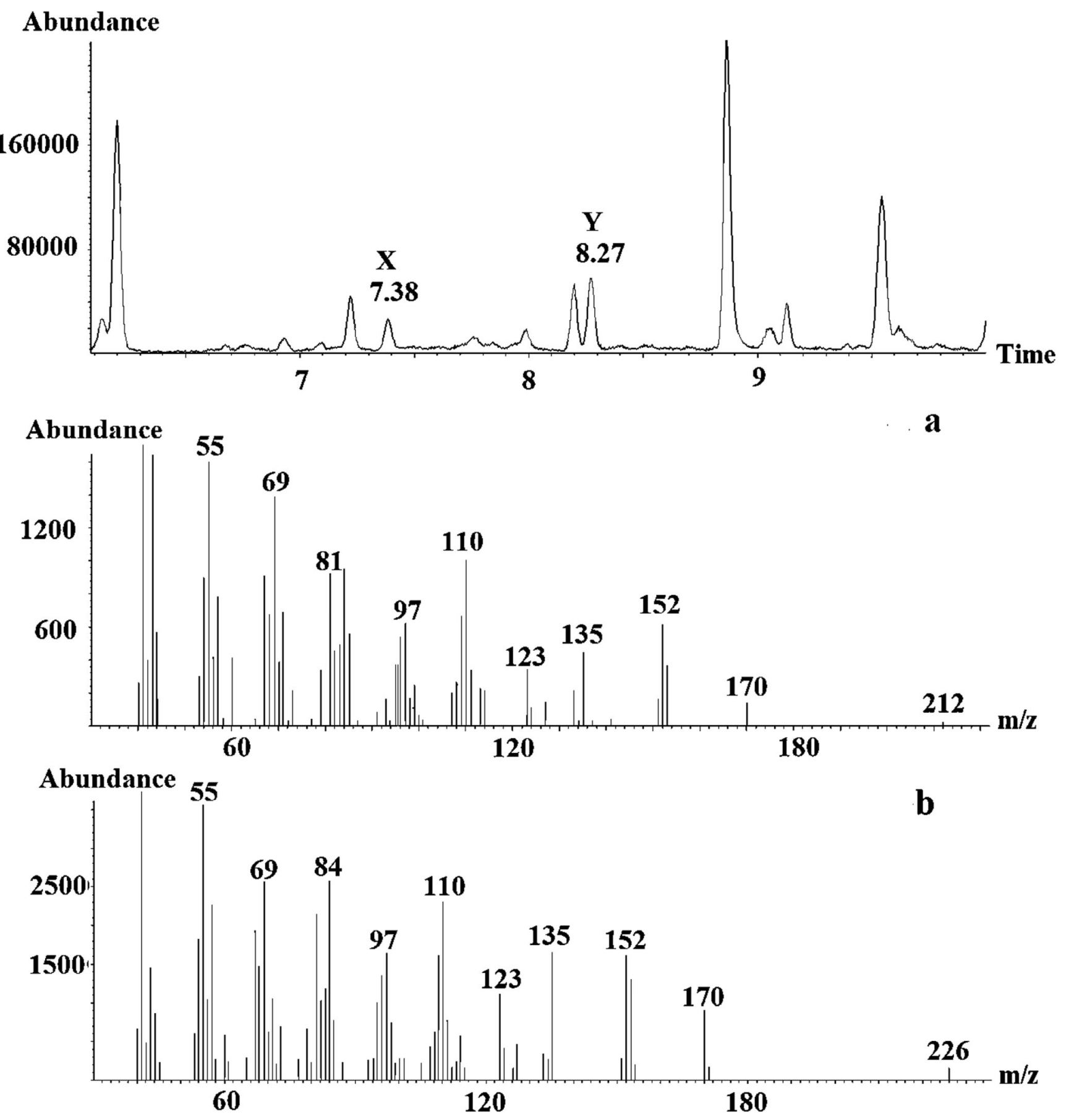

Fig. 2 Part of the gas chromatogram (Vf-23 ms column) of a Whittleia retiella female extract and the mass spectra of (a), the first unknown antennally active compound $(\mathrm{X})$ eluting at $7.38 \mathrm{~min}$ and (b), the second unknown antennally active compound (Y) eluting at $8.27 \mathrm{~min}$

conceivable to postulate that $\beta$-oxidation could chain shorten a (7Z)-C12-precursor to (5Z)-decenoic acid. Consequently, we synthesised 1-methylpropyl (5Z)-dec-5-enoate, and found that its retention time matched that of Y. Nevertheless, to be on the safe side, we synthesized the (5E)-isomer as well as $E / Z$ - isomers of esters carrying the double bond in positions 4 or 6 and compared the retention times of these compounds with that of Y (Fig. 3).

The retention time of 1-methylpropyl (5Z)-dec-5enoate ( $\left.2 \mathrm{~d}^{\prime}\right)$ coincided with that of compound $\mathrm{Y}$ in the 
Fig. 3 Part of the gas chromatogram (CP-WAX 58 column) of (a) 1-methylpropyl $(4 E)$-dec-4-enoate (2c), 1methylpropyl (4Z)-dec-4-enoate (2c'), 1-methylpropyl (5E)-dec-5enoate (2d), 1-methylpropyl (5Z)dec-5-enoate ( $\left.2 \mathrm{~d}^{\prime}\right)$, and 1methylpropyl $E / Z$-dec-6-enoate (2e) (b) Whittleia retiella female extract with compound $\mathrm{Y}$ eluting at $33.52 \mathrm{~min}$
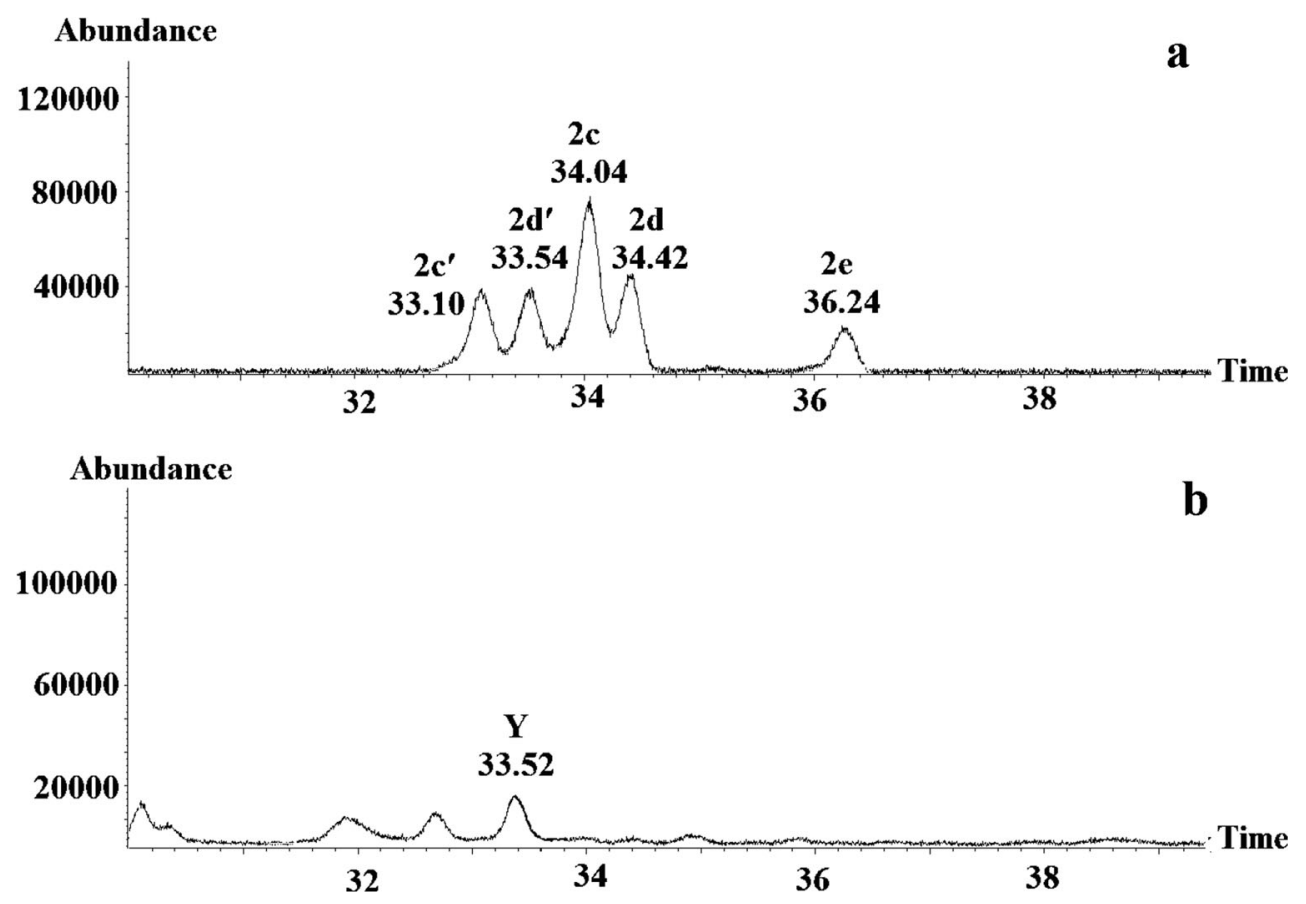

female extract, whereas the other candidate compounds, including 1-methylpropyl (5E)-dec-5-enoate (2d), did not and were excluded from the investigation. As the mass spectra of 1-methylpropyl (5Z)-dec-5-enoate and that of the natural product $\mathrm{Y}$ were very similar, it was concluded that 1-methylpropyl (5Z)-dec-5-enoate represented compound $\mathrm{Y}$, eluting at $8.27 \mathrm{~min}$ (Fig. 4).

1-Methylpropyl (5Z)-dec-5-enoate has a chiral center and thus exists as two enantiomers (Fig. 5). To conclusively determine the absolute configuration of the $W$. retiella compound, both enantiomers were synthesised (see Supplementary Material for details) and submitted to enantioselective gas chromatography.

The retention time of $Y$ was compared with retention times of a reference ester mixture of known enantiomeric composition as proven by enantioselective GC (Fig. 6 B). By mixing appropriate volumes of the natural extract and the synthetic mixture of enantiomers in the GC-syringe (co-injection), an increase of the peak representing (1S)-1-methylpropyl (5Z)dec-5-enoate is noted (Fig. 6c), which shows Y to be (1S)-1methylpropyl (5Z)-dec-5-enoate.

For structure elucidation of $\mathrm{X}$, similar GC-MS investigations as for $\mathrm{Y}$ were performed using corresponding 1methylethyl decenoates as reference compounds (Fig. 7). It turned out that the mass spectra of 1-methylethyl (4Z)dec-4-enoate (3c') and 1-methylethyl (5Z)-dec-5-enoate ( $\left.3 \mathrm{~d}^{\prime}\right)$ were almost identical, and the retention time of both compounds nearly coincided with that of X, but the the latter eluted slightly closer (Fig. 8). However, the other analysed structures could be excluded from the investigation, due to differences in retention times. Consequently, 1-methylethyl (5Z)-dec-5-enoate was regarded to be the electrophysiologically active component $\mathrm{X}$, eluting at $7.38 \mathrm{~min}$.

Field Bioassays In 2017, three tests at Mulbjerge/Dokkedal revealed attraction of several males to the baits (1: May 15, four males; 2: May 17, one male, and 3: May 22, six males). In 2018, one test at Mulbjerge/Dokkedal (4: May 14) brought two males approaching the baits of series 1 , although both series were used, and one test at Kongenshus Hede (5: May 15) brought ten males using only the bait series 2 . Males were clearly attracted to the baits and preferentially visited a subset of the baits on display (Table 2 and 3). No approaches were observed to control baits with $n$-hexane. Visits occurred to all baits loaded with the main component (1S)-1-methylpropyl (5Z)-dec-5-enoate at $100 \mu \mathrm{g}$, either as a single component or with additions of 1-methylethyl (5Z)dec-5-enoate at doses from 10 to $50 \mu \mathrm{g}$. At two of the observation periods, visiting males also approached a bait containing $100 \mu \mathrm{g}$ racemic 1-methylpropyl (5Z)-dec-5-enoate and $30 \mu \mathrm{g}$ 1-methylethyl (5Z)-dec-5-enoate. No attraction was observed to baits containing (1R)-1-methylpropyl (5Z)dec-5-enoate alone or in combination with 1-methylethyl (5Z)-dec-5-enoate. No flying males were ever observed apart from those attracted to the baits on display, and no other moth species were observed approaching the baits. Although bioassays often lasted for the better part of a 
Fig. 4 Part of the gas chromatogram (Vf-23 ms column) and mass spectra of (a) 1-methylpropyl (5Z)-dec-5enoate and (b) compound $\mathrm{Y}$, eluting at $8.27 \mathrm{~min}$ in the Whittleia retiella female extract
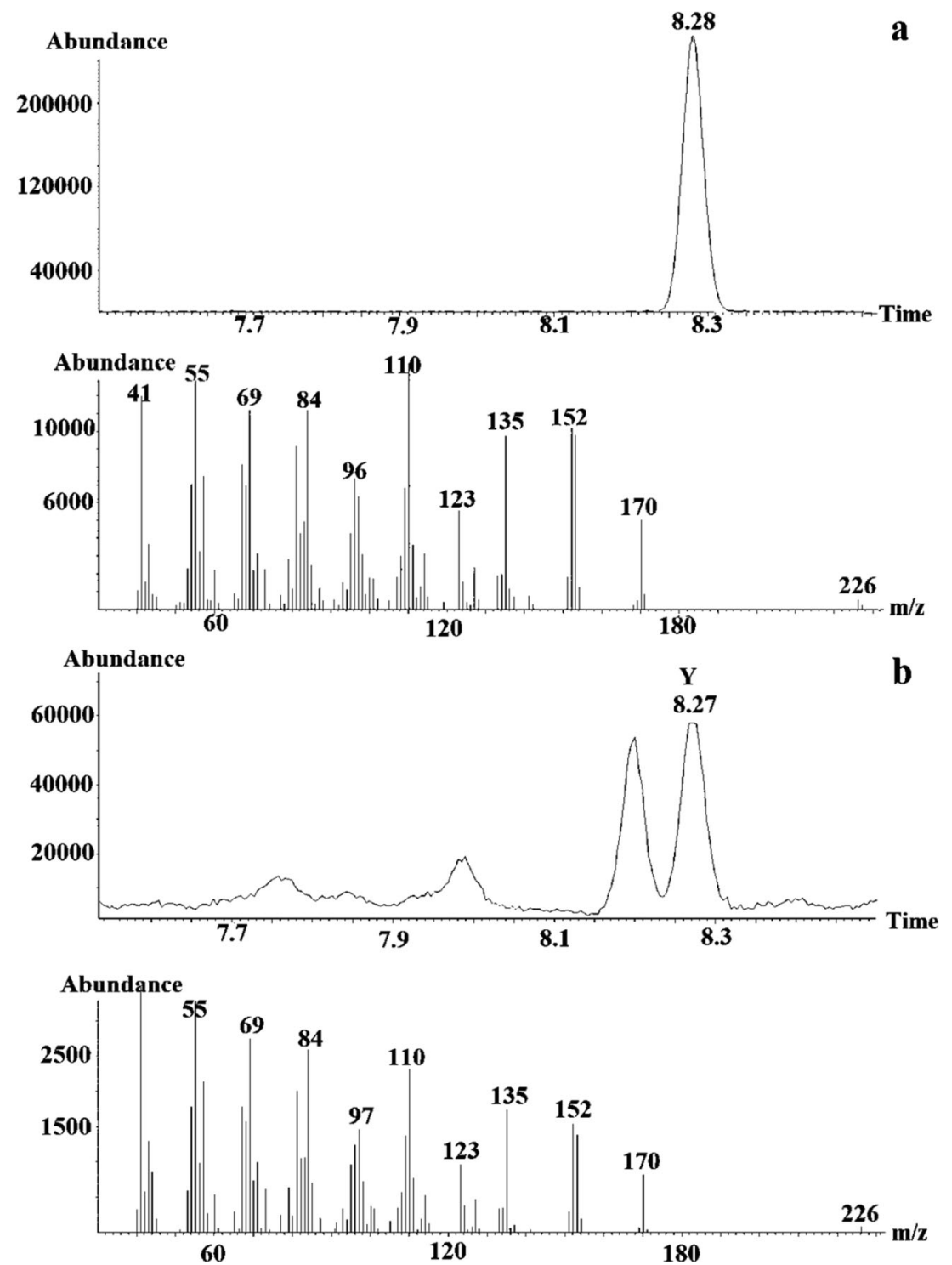

day, all observations of males attracted to baits occurred between 12.00 and 14.00 .

\section{Discussion}

The baits of each observer were only brought out of the freezers during less than 14 partial days in total over the course of four years, which is less time in the field than many regular field seasons, when baits are normally left continuously in traps. The compounds are stable and have similar molecular weights and likely similar vapour pressures, so we do not expect their relative ratios in the baits to change much over time. The behavioural attraction to the main component was evident, with little possibility to differentiate with regard to the importance of

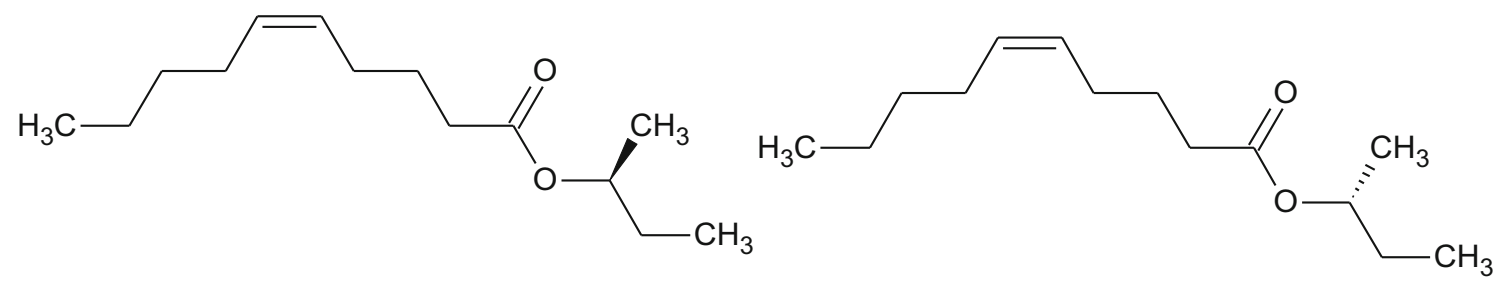

Fig. 5 Chemical structures of the two enantiomers of 1-methylpropyl (5Z)-dec-5-enoate obtained via CRL catalysed esterification of (5Z)-dec-5-enoic acid using pure enantiomers of (2S)-butan-2-ol and ( $2 R)$-butan-2-ol, respectively 


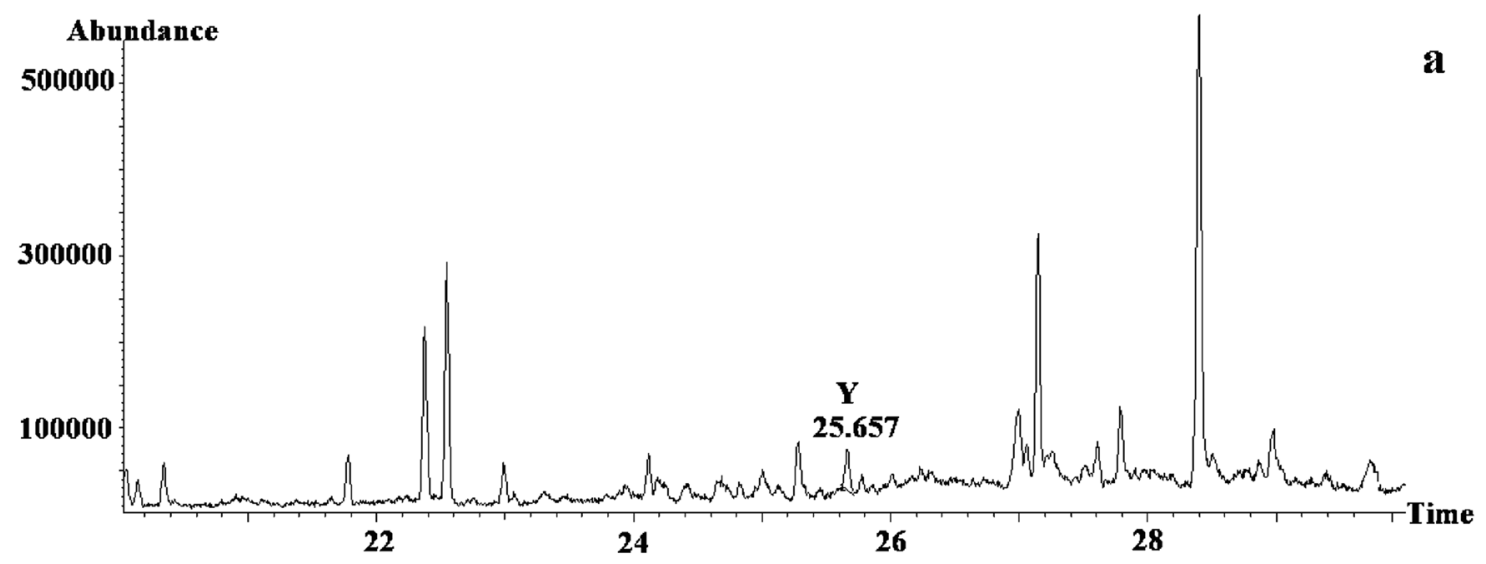

Abundance
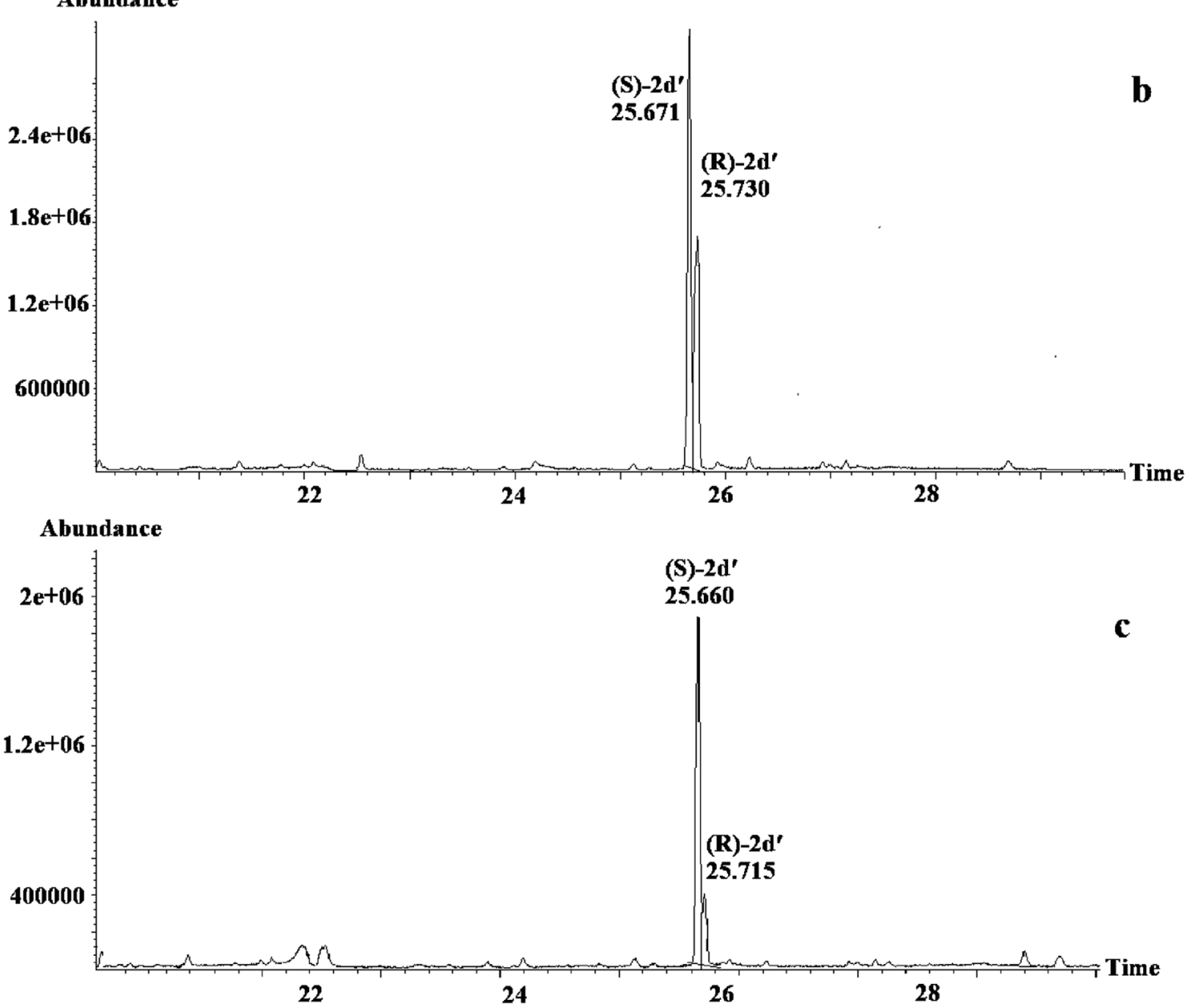

Fig. 6 Part of the gas chromatogram (Cyclosil-B) of (a) Whittleia retiella female extract, (b) mixture of (1S)-1-methylpropyl (5Z)-dec-5-enoate and (1R)-1-methylpropyl (5Z)-dec-5-enoate, (c) (1S)-1-methylpropyl (5Z)-

the secondary component in the current setup, and the degree of confidence in the ratios was likely relevant for the situation at hand. Our electrophysiological and dec-5-enoate and (1R)-1-methylpropyl (5Z)-dec-5-enoate mixed with $W$. retiella female extract

behavioural data suggest that the female-produced sex pheromone of the halobiotic psychid $W$. retiella consists of (1S)-1-methylpropyl (5Z)-dec-5-enoate, and possibly 
Fig. 7 Part of the gas chromatogram (CP-WAX 58 column) of (a) 1-methylethyl $(4 E)$-dec-4-enoate $(3 \mathrm{c}), 1$ methylethyl (4Z)-dec-4-enoate (3c'), 1-methylethyl (5E)-dec-5enoate (3d), 1-methylethyl (5Z)dec-5-enoate (3d'), 1-methylethyl dec-6-enoate (3e) and (b) Whittleia retiella female extract with the natural product $\mathrm{X}$ eluting at $23.09 \mathrm{~min}$

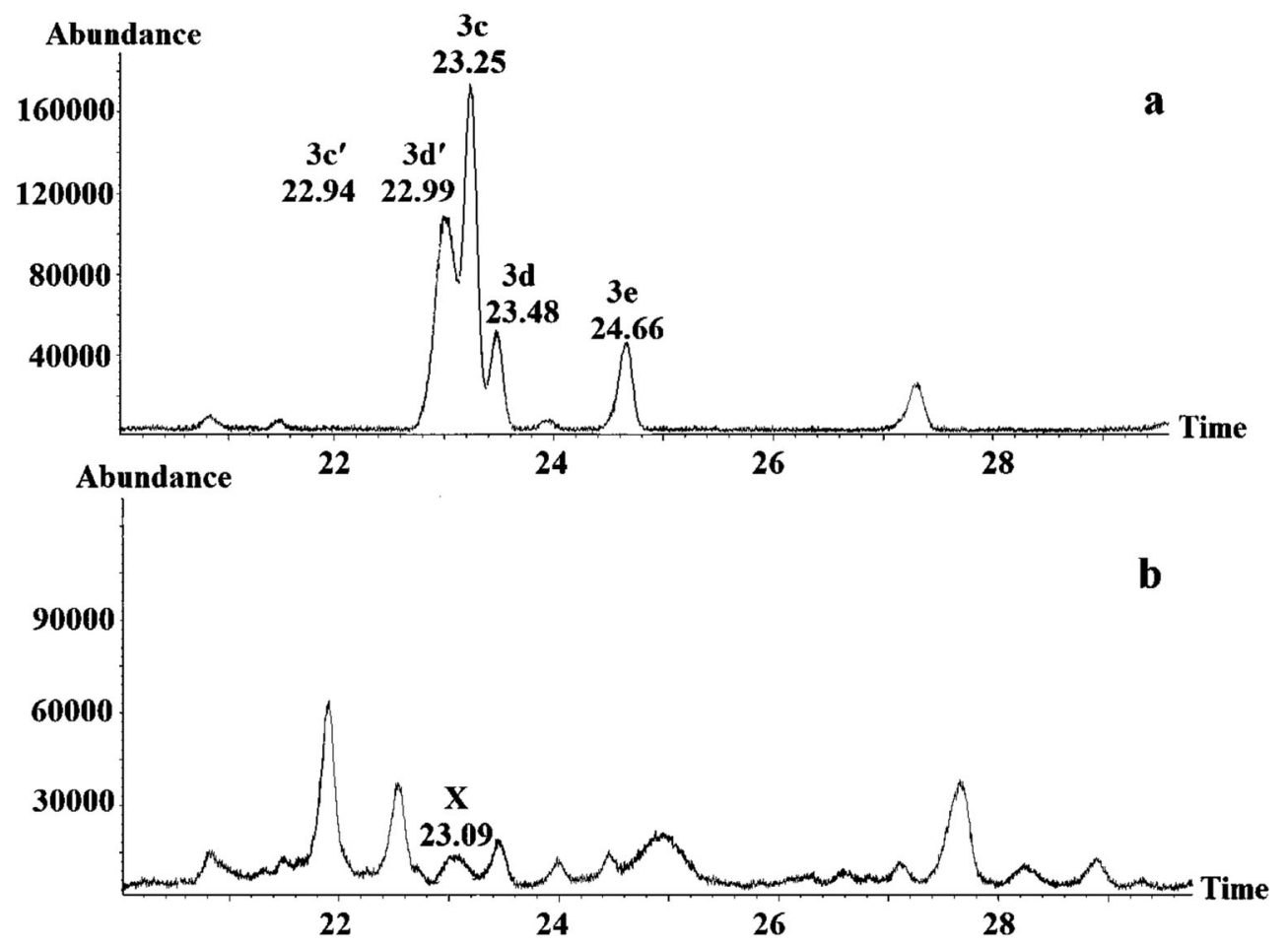

also 1-methylethyl (5Z)-dec-5-enoate. The field bioassays revealed a preference of males towards baits containing (1S)-1-methylpropyl (5Z)-dec-5-enoate (Table 2 and 3). No visits were recorded to blank baits or to baits with 1-methylethyl (5Z)-dec-5-enoate or the non-natural enantiomer, (1R)-1-methylpropyl (5Z)-dec-5-enoate, as the main constituents (Table 2). The role of 1 methylethyl (5Z)-dec-5-enoate as a pheromone component could not be conclusively established from these few observations. Baits with only (1S)-1-methylpropyl (5Z)-dec-5-enoate were among the most preferred baits at two occasions with the highest numbers of visiting males, suggesting that 1-methylethyl (5Z)-dec-5-enoate is not behaviourally active, but there is a possibility that the presence of the latter compound among adjacent baits may have contributed to the attraction. There is a recorded case where male moths, once activated by the complete blend of a female pheromone, display lower selectivity during the subsequent search for the pheromone source (Karpáti et al. 2013).

The attraction to the baits containing the $S$-enantiomer was evident, as opposed to the lack of approaches to controls or baits lacking the $S$-enantiomer, whereas the relative numbers of approaches to different ratios of the secondary component were not possible to distinguish quantitatively for individual males, preventing any form of rigorous statistical testing.

Pheromone identifications in bagworms are still scarce, and W. retiella is the fifth species for which a detailed investigation has been performed. All psychid species analysed so far use esters of long-chain fatty acids as sex pheromones. Leonhardt et al. (1983) identified (R)-1-methylbutyl decanoate as sex pheromone of Thyridopteryx ephemeraeformis (Haworth), and the same compound and four additional esters were found to constitute the sex pheromone of Oiketicus kirbyi (Guilding) (Rhainds et al. 1994). Subchev et al. (2000) reported 1methylethyl octanoate as sex pheromone of Megalophanes viciella (Denis \& Schiffermüller). More recently, Gries et al. (2006) revealed two antennally active compounds in females of Clania variegata (Snellen), and the most abundant compound was identified as (1S)-1-ethyl-2-methylpropyl 3,13dimethylpentadecanoate. The use of long-chain fatty acid esters as sex pheromone components outside the bagworm family seems to be restricted, and so far only revealed for species belonging to the subfamily Procridinae within the Zyganidae, e.g. (1S)-1-methylpropyl (7Z)-tetradecenoate in Theresimima ampellophaga Bayle-Barelle (Subchev et al. (1998), and (1R)1-methylpropyl (7Z)-dodecenoate and (1R)-1-methylpropyl (9Z)-tetradecenoate in Illiberis rotundata Jordan (Subchev et al. 2009). In both Psychidae and Procridinae enantiomeric specificity in the pheromone channel is apparent, whereas the opposite enantiomers of a pheromone component are inactive or even inhibit male attraction.

Monitoring with an efficient sex pheromone is a valuable conservation tool when gathering information about the geographic distribution and habitat requirements of rare and threatnend insect species. Detection of 
Fig. 8 Part of the gas chromatogram (Vf-23 ms column) and the mass spectra of (a) 1-methylethyl (5Z)-dec-5enoate, (b) 1-methylethyl (4Z)dec-4-enoate, and (c) the natural product $\mathrm{X}$, eluting at $7.38 \mathrm{~min}$ in the Whittleia retiella female extract
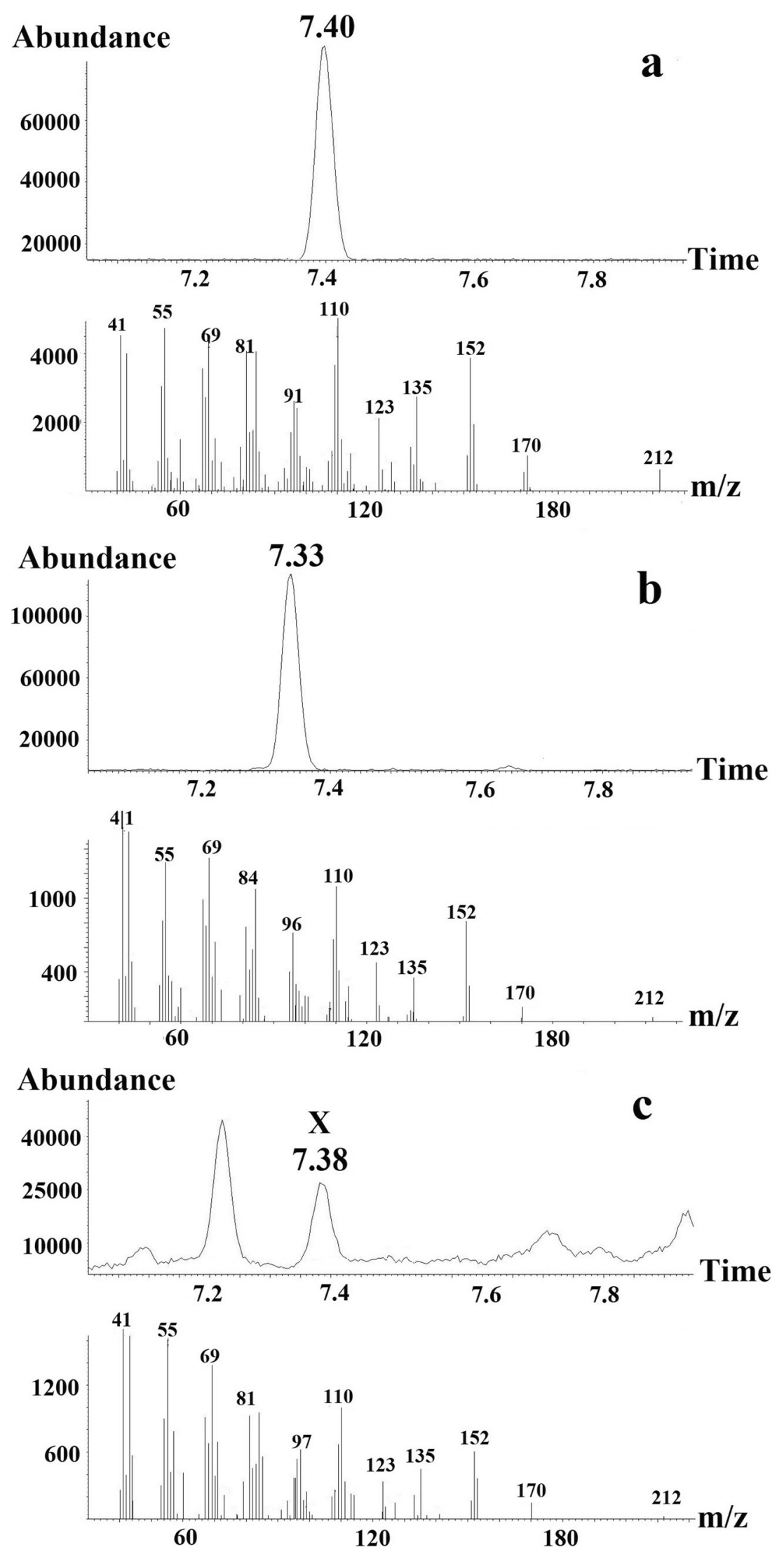
Table 2 Attraction of Whittleia retiella males to bait series 1 at four different field observations in 2017 (Obs 1-3) and 2018 (Obs 4)

\begin{tabular}{|c|c|c|c|c|c|c|c|c|c|c|c|c|}
\hline \multirow{2}{*}{$\begin{array}{l}\text { Compound } \\
\text { Isoprop-C5DA }\end{array}$} & \multicolumn{12}{|c|}{ Bait composition } \\
\hline & & & 10 & 30 & & 30 & 10 & 30 & 100 & & 10 & 30 \\
\hline (rac)-2b-C5DA & & & & & 200 & 200 & 100 & 100 & & & & \\
\hline$(S)-2 \mathrm{~b}-\mathrm{C} 5 \mathrm{DA}$ & & & & & & & & & & 100 & 100 & 100 \\
\hline (R)-2b-C5DA & & 100 & 100 & 100 & & & & & & & & \\
\hline Blank & $\mathrm{BL}$ & & & & & & & & & & & \\
\hline Obs $1 N=4$ & & & & & & & & $\bullet$ & & $\bullet$ & & $\bullet$ \\
\hline Obs $2 N=1$ & & & & & & & & $\bullet$ & & $\bullet$ & & $\bullet$ \\
\hline Obs $3 N=6$ & & & & & & & & $\bullet$ & & $\bullet$ & & $\bullet$ \\
\hline Obs $4 N=2$ & & & & & & & & $\bullet$ & & & & $\bullet$ \\
\hline
\end{tabular}

Isoprop-C5DA = 1-methylethyl (5Z)-dec-5-enoate, 2b-C5DA = 1-methylpropyl (5Z)-dec-5-enoate. Different enaniomeric composition of $2 \mathrm{~b}-\mathrm{C} 5 \mathrm{DA}$ ( $S, R$ or racemic) is indicated. Numbers represent $\mu \mathrm{g}$ loading of different synthetic compounds on the baits. Blank baits were loaded with $n$-hexane (hx) only. Black dots represent baits visited by one or more males at each observation, respectively. $\mathrm{N}=$ number of approaching males at each observation. At all occasions, the baits were displayed in parallel with bait series 2 (see Table 3 )
W. retiella populations in salt marsh habitats would be greatly facilitated by implementing a monitoring system using baits loaded with (2S)-1-methylpropyl (5Z)-dec-5enoate. The species has been recorded in Great Britain, France, Germany, Belgium, Holland, Denmark, and Sweden (Rickert et al. 2009), but high resolution data on its distribution are lacking. Because $W$. retiella is small and only flies at sunny days during a short period of spring, it may have been overlooked. This identification of the pheromone of $W$. retiella included few females, and the pheromone is produced in minute amounts. Thus, further optimisiation of the pheromone may be needed, e.g. testing different doses of (2S)-1-methylpropyl (5Z)-dec-5enoate applied on septa and the role of 1-methylethyl

Table 3 Attraction of Whittleia retiella males to bait series 2 at four different field observations in 2017 (Obs 1-3) and 2018 (Obs 4-5)

\begin{tabular}{lcllll}
\hline Compound & Bait composition & & & \\
\hline $\begin{array}{l}\text { Isoprop-C5DA } \\
\text { (S)-2b-C5DA }\end{array}$ & 100 & & 10 & 30 & 50 \\
Blank & BL & 100 & 100 & 100 & 100 \\
Obs $1 \mathrm{~N}=4$ & & & & & \\
Obs $2 \mathrm{~N}=1$ & & $\bullet$ & & $\bullet$ \\
Obs $3 \mathrm{~N}=6$ & $\bullet$ & & $\bullet$ \\
Obs $4 \mathrm{~N}=2^{*}$ & & $\bullet$ & & $\bullet$ \\
Obs $5 N=10$ & & $\bullet$ & $\bullet$ & $\bullet$ & $\bullet$ \\
\hline
\end{tabular}

Isoprop-C5DA = 1-methylethyl (5Z)-dec-5-enoate and $(S)$-2b-C5DA = $1 S$-methylpropyl (5Z)-dec-5-enoate. Numbers represent $\mu \mathrm{g}$ loading of different synthetic compounds on the baits. Blank baits were loaded with $n$-hexane (hx) only. Black dots represent baits visited by one or more males at each observation, respectively. $\mathrm{N}=$ number of approaching males at each observation. At observations $1-4$, the baits were displayed in parallel with bait series 1 (see Table 2)

*No visits from males to bait series 2 at this occasion, but to bait series 1 , which was displayed in parallel
(5Z)-dec-5-enoate as potential pheromone component to improve the attraction of males to baits in the field.

Acknowledgements We would like to thank Kristian Knudsen, Svend Bagger Larsen, Eivind Palm and Uffe Terndrup for conducting the field observations in Denmark; the European Union Europe Regional Development Fund, the County Administrative Board of Västernorrland, the Marie Claire Cronstedt Foundation, the Swedish Environmental Protection Agency (project NV-03135-14) and the Swedish Research Council for Environment, Agricultural Sciences and Spatial Planning (projects 239-2013-669 and 2016-01372) for financing.

Funding Information Open access funding provided by Mid Sweden University.

Open Access This article is licensed under a Creative Commons Attribution 4.0 International License, which permits use, sharing, adaptation, distribution and reproduction in any medium or format, as long as you give appropriate credit to the original author(s) and the source, provide a link to the Creative Commons licence, and indicate if changes were made. The images or other third party material in this article are included in the article's Creative Commons licence, unless indicated otherwise in a credit line to the material. If material is not included in the article's Creative Commons licence and your intended use is not permitted by statutory regulation or exceeds the permitted use, you will need to obtain permission directly from the copyright holder. To view a copy of this licence, visit http://creativecommons.org/licenses/by/4.0/.

\section{References}

Ahrné K, Bengtsson B, Björklund JO, Cederberg B, Eliasson C, Hydén N, Jonasson J, Lindeborg M, Ohlsson A, Palmqvist G \& Ryrholm N (2015) Rödlistade fjärilar, Redlisted butterflies and moths (Lepidoptera). In Gärdenfors, U.(ed) Rödlistade arter i Sverige 2015. ArtDatabanken SLU, pp 98-112

Barbour JD, Millar JG, Rodstein J, Ray AM, Alston DG, Rejzek M, Dutcher JD, Hanks LM (2011) Synthetic 3,5-dimethyldodecanoic acid serves as a general attractant for multiple species of Prionus (Coleoptera: Cerambycidae). Ann Entomol Soc Am 104:588-593 
Bengtsson BÅ, Palmqvist G (2008) Nationalnyckeln till Sveriges flora och fauna. Fjärilar: Käkmalar - säckspinnare. Lepidoptera: Micropterigidae - Psychidae. ArtDatabanken, SLU, Uppsala, Sweden

Binot M, Bless R, Boye P, Gruttke H, Pretscher P (1998) Rote liste gefährdeter Tiere Deutschlands (Bundesamt für Naturschutz). Schriftenreihe für Landschaftspflege und Naturschutz Heft 55: $1-434$

Bowden K, Heilbron IM, Jones ERH, Weedon BCL (1946) Researches on acetylenic compounds. Part I. the preparation of acetylenic ketones by oxidation of acetylenic carbinols and glycols. J Chem Soc (resumed) (0):39-45. https://doi.org/10.1039/jr9460000039

Burman N, Westerberg L, Ostrow S, Ryrholm N, Bergman KO, Winde I, Nyabuga FN, Larsson MC, Milberg P (2016) Revealing hidden biodiversity and potential polyphagy with pheromones: the case of Synanthedon vespiformis (Lepidoptera: Sesiidae) in Sweden. J Insect Conserv 20:1121. https://doi.org/10.1007/s10841-015-9835-9

Chang CS, Hsu CS (2003) Lipase-catalyzed enantioselective esterification of $(S)$-naproxen hydroxyalkyl ester in organic media. Biotechnol Lett 25(5):413-416. https://doi.org/10.1023/a: 1022948009889

Francke W, Lübke G, Schröder W, Reckziegel A, Imperatriz-Fonseca V, Kleinert A, Engels E, Hartfelder K, Radtke R, Engels W (2000) Identification of oxygen containing volatiles in dephalic secretions of workers of Brazilian stingless bees. J Braz Chem Soc 11:562-571

Gries R, Khaskin G, Tan ZX, Zhao BG, King GGS, Miroshnychencko A, Lin GQ, Rhainds M, Gries G (2006) (1S)-1-Ethyl-2-methylpropyl 3, 13-dimethylpentadecanoate: major sex pheromone domponent of Paulownia bagworm, Clania variegata. J Chem Ecol 32:1673-1685

Harvey DJ, Vuts J, Hooper A, Finch P, Woodcock CM, Caulfield JC, Kadej M, Smolis A, Withall DM, Henshall S, Pickett JA, Gange AC, Birkett MA (2018) Environmentally vulnerable noble chafers exhibit unusual pheromone-mediated behaviour. PLoS One 13:15. https://doi.org/10.1371/journal.pone.0206526

Heppner JB (2008) Bagworm moths (Lepidoptera: Psychidae). Encyclopedia of Entomology. Springer, Dordrecht, pp 358-358. https://doi.org/10.1007/978-1-4020-6359-6

Karpáti Z, Tasin M, Carde RT, Dekker T (2013) Early quality assessment lessens pheromone specificity in a moth. Proc Natl Acad Sci U S A 110:7377-7382. https://doi.org/10.1073/pnas.1216145110

Koenig C, Steidle JLM, Tolasch T (2015) Decrypting cryptic click beetle species by analysis of sex pheromones. J Chem Ecol 41:740-745. https://doi.org/10.1007/s10886-015-0606-6

Koenig C, Szallies A, Steidle JLM, Tolasch T (2016) Sex pheromone of the rare click beetle Betarmon bisbimaculatus. J Chem Ecol 42:5559. https://doi.org/10.1007/s10886-015-0661-z

Kosi AZ, Zou YF, Hoskovec M, Vrezec A, Stritih N, Millar JG (2017) Novel, male-produced aggregation pheromone of the cerambycid beetle Rosalia alpina, a priority species of European conservation concern. PLoS One 12:19. https://doi. org/10.1371/journal.pone. 0183279

Larsson MC (2016) Pheromones and other semiochemicals for monitoring rare and endangered species. J Chem Ecol 42:853-868. https:// doi.org/10.1007/s10886-016-0753-4

Larsson MC, Svensson GP (2005) Methods in insect sensory ecology. In: Christensen TA (ed) Methods in insect sensory neuroscience. CRC Press, New York, pp 27-58

Larsson MC, Hedin J, Svensson GP, Tolasch T, Francke W (2003) Characteristic odor of Osmoderma eremita identified as a malereleased pheromone. J Chem Ecol 29:575-587. https://doi.org/10. 1023/A:1022850704500

Leonhardt BA, Neal JW Jr, Klun JA, Schwarz M, Plimmer JR (1983) An unusual lepidopteran sex pheromone system in the bagworm moth. Science 219:314-316. https://doi.org/10.1126/ science.219.4582.314

Millar JG, McElfresh JS, Romero C, Vila M, Mari-Mena N, LopezVaamonde C (2010) Identification of the sex pheromone of a protected species, the spanish moon moth Graellsia isabellae. J Chem Ecol 36:923-932. https://doi.org/10.1007/s10886-0109831-1

Molander MA, Larsson MC (2018) Identification of the aggregation-sex pheromone of the cerambycid beetle Phymatodes pusillus ssp pusillus and evidence of a synergistic effect from a heterospecific pheromone component. J Chem Ecol 44:987-998. https://doi.org/ 10.1007/s10886-018-1008-3

Molander MA, Helgesson J, Winde IB, Millar JG, Larsson MC (2019) The male-produced aggregation-sex pheromone of the cerambycid beetle Plagionotus detritus ssp. detritus. J Chem Ecol 45:28-36. https://doi.org/10.1007/s10886-018-1031-4

Rhainds M, Gries G, Li J, Gries R, Slessor KN, Chinchilla CM, Oehlschlager AC (1994) Chiral esters: sex pheromone of the bagworm, Oiketicus kirbyi (Lepidoptera: Psychidae). J Chem Ecol 20: 3083-3096

Rickert C (2010) Microlepidoptera in salt marshes- life history, effects of grazing and their suitability as ecological indicators. Dissertation, University of Kiel

Rickert C, Roweck H, Sobczyk T (2009) Whittleia retiella (Newman, 1847) (Psychidae) from the salt marshes of Schleswig-Holstein, Germany, with descriptive and life-history notes. Nota Lepidopterol 32(2):123-127

Ryrholm N (2005) Artfaktablad Whittleia retiella (Psychidae), ArtDatabanken, SLU, Uppsala, Sweden

Sabbani S, Hedenström E, Andersson J (2007) Lipase catalyzed acylation of primary alcohols with remotely located stereogenic centres: the resolution of $( \pm)$-4,4-dimethyl-3-phenyl-1-pentanol. Tetrahedron Asymmetry 18(14):1712-1720. https://doi.org/10.1016/j.tetasy. 2007.07.002

Subchev M, Harizanov A, Francke W, Franke S, Plass E, Reckziegel A, Schröder F, Pickett JA, Wadhams LJ, Woodcock CM (1998) Sex pheromone of female vine bud moth, Theresimima ampellophaga comprises (2S)-butyl (7Z)-tetradecenoate. J Chem Ecol 24:11411151 Erratum: J Chem Ecol (1999) 25:1203

Subchev M, Toshova T, Stanimirova L, Stan GH, Embacher G, Francke W, Reckziegel A, Ferreira JT, Priesner E (2000) 1-Methylethyl octanoate, a new Lepidopteran sex pheromone from the bagworm, Megalophanes viciella. J Chem Ecol 26:487-495

Subchev M, Toshova T, Koshi C, Franke S, Tröger A, Twele R, Francke W, Pickett JA, Wadhams LJ, Woodcock CM (2009) Identification and biological activity of sex pheromone components from females of the plum moth Illiberis rotundata Jordan (Lepidoptera: Zygaenidae: Procridinae). Chemoecology 19:47-54

Svensson GP, Oleksa A, Gawroński R, Lassance JM, Larsson MC (2009) Enantiomeric conservation of the male-produced sex pheromone facilitates monitoring of threatened European hermit beetles (Osmoderma spp.). Entomol Exp Appl 133(3):276-282. https:// doi.org/10.1111/j.1570-7458.2009.00923.x

Tolasch T, Fragstein M, Steidle JLM (2007) Sex pheromone of Elater ferrugineus L. (Coleoptera: Elateridae). J Chem Ecol 33:21562166. https://doi.org/10.1007/s10886-007-9365-3

Witzgall P, Kirsch P, Cork A (2010) Sex pheromones and their impact on pest management. J Chem Ecol 36(1):80-100. https://doi.org/10. 1007/s10886-009-9737-y

Wube AA, Huefner A, Thomaschitz C, Blunder M, Kollroser M, Bauer $\mathrm{R}$, Bucar F (2011) Design, synthesis and antimycobacterial activities of 1-methyl-2-alkenyl-4(1H)-quinolones. Bioorg Med Chem 19: 567-579. https://doi.org/10.1016/j.bmc.2010.10.060 